\title{
Exploration of Morphological Diversity of Cacao Plant (Theobroma cacao L.) in Bacan Island
}

\author{
Suratman Sudjud ${ }^{1, *}$, Shubzan Andi Mahmud ${ }^{1}$, Chykita Anggraeni Djafar ${ }^{1}$ \\ ${ }^{I}$ Department of Agrotechnology, Faculty of Agriculture, Universitas Khairun, Ternate, Indonesia \\ "Corresponding author. Email: suratmansudjud@ gmail.com
}

\begin{abstract}
This study aims to determine the types of cocoa plants and family relationships that exist in Kampung Makian Village and Papaloang Village. The research method used a descriptive method by looking at the morphological markers of the cocoa plant as a diversity differentiator. The analysis used to determine the kinship relationship is the analysis of cluster and ANOVA tests, then a dendrogram is produced which can describe the relationships between trees. The step of the research was started with field observations and then determining the sampling village, followed by sampling the one that was in accordance with the descriptor of the cocoa plant morphology. The dendrogram shows that there is a kinship that is very close between trees, but there are also those who have distant kinship. Cocoa plants in Kampung Makian Village and Papaloang Village have high diversity. There are liam types of cocoa plants according to their form in the village of Kamoung Makian and Paploang Village, namely forastero, angoleta, cundeamor, amelonado, and calbacillo.
\end{abstract}

Keywords: cocoa plants, morphological diversity, family relationship

\section{INTRODUCTION}

Distribution of cocoa commodities in Indonesia according to history that cocoa plants developed into 22 genera theobroma but commercially cultivated only cocoa plants with taxa classification including; Divisio Spermatophyta sub division Angiospermae, Dicotyledoneae Klassis, Order Malvales, Family Sterculiaceae, Genus Theobroma, Theobroma Cocoa L. Species (Prabowo, 2008). The decline in cocoa production and productivity is generally caused by several factors, such as aging of plants, the use of non-quality planting material, high intensity of pest and disease attacks and lack of garden maintenance by farmers. One of the steps taken to overcome the decline in cocoa production and productivity is the presence of a national cocoa production and quality improvement movement known as the cocoa gernas program whose main objective is to accelerate cocoa production and quality improvement (Directorate General of Plantations, 2008). But the program was considered less successful by the community and could not increase cocoa production, productivity, and quality. In increasing the amount of production and quality of cocoa beans, the aspect that is most considered is use of superior seeds (Mertade and Basri, 2011). Therefore superior seeds must-have characteristics of high yield, high-quality seeds, and resistant to pests and diseases. Superior seeds are obtained from direct exploration in the field (plantations) but in their development, superior seeds are assembled from the crossing of the elders who have the desired advantage. The success of the high-yielding seed assembly business is very dependent on the availability of accurate information about the diversity of varieties/clones of cocoa plants (Rubiyo, 2009). Efforts to resolve the problem need to be done in an integrated manner between various components of cultivation. Planting material is a component that underlies the success of the crop cultivation process, but until now the adoption of superior cocoa planting material is still relatively low. North Maluku has been known for a long time as a producer of spices. But many do not know that North Maluku, especially in the Halmahera region, namely Bacan Island, has produced cocoa with a relatively large amount of production. In 2010 up to 2014, cocoa production was one of the indicators of interference for North Maluku in developing and improving the country.

\section{METHODS}

This This research was carried out in Bacan Island with sampling locations in the villages of Kampung Makian and Papaloang Village, which took place from July 2018 to October 2018.

The tool used in research

This includes stationery, questionnaire, camera as a documentation tool, meter, knife, GPS, cacao plant descriptor guide (Engles et al., 1989) as guidelines for 
morphological characterization. The material used in this study was the population of cocoa plants in each location of the study sample.

The method used in this research is descriptive method with direct observation technique on the observed object. Data on plant morphology characters were obtained through surveys and direct observations on sample plants in the field based on the cocoa plant descriptor guidelines.

\section{Data Types and Sources}

The data taken is primary data through direct observation at the study site including the type and morphology description of cocoa plants, location of growth and habitat. For the study of Morphology and Agronomy productive cocoa trees are taken.

\section{Research procedure}

The stages of the implementation of research activities to identify the diversity and kinship of cocoa plants in Bacan Island are carried out through several stages, namely:

\section{Observation in the Field}

The initial activity was carried out in the identification of cocoa plants by conducting direct observations in two villages on Bacan Island, which aimed to find out the research target areas that had a variety of cocoa plant populations.

\section{Determination of Research Location}

From the observations, the location of the study is determined proportionally, which is the area that has a variety of cacao plants. The location of the study was determined in two districts namely Central Bacan and East Bacan sub-districts, assuming that the sub-district has a diversity of cocoa plants.

\section{Sampling Technique for Plant Sampling}

Sampling of plants or sampling is done based on selective variations of sample plants at the study site. The number of sample plants observed at each location for the same type is taken 10 (ten) sample plants, from each plant 10 samples are taken for each character observation morphology. Sample plants or sample plants taken are plants that have vigor and good viability.

\section{Observed parameters}

Morphological characterization is done to recognize the characteristics of an accession character which also functions as a reader character between accessions. Characterization activities are carried out based on the morphological character of the main plant organ identifiers, among others, trees, leaves, flowers and fruit. Characterization data should be supplemented with photographs of plant parts that are characterized, for example fruit or flush color. The characterization guidelines refer to the text compiled by Engels et. al (1980). The following parameters were observed:

Habitus Shape, Plant Height, Canopy Length Width, Branching Shape, Jorket Formation, Plagiotropic Branch Corner, Old Leaf Color Tinge, Young Leaf Color, Leaf Length, Leaf Width, Leaf Shape, Leaf Edge Shape, Leaf Edge Shape, Leaf Leaves, Leaf Texture, Stalk Leaves, Flower Stalk Color, Flower Stalk Length, Fruit Length, Fruit Width, Fruit Size Based on Length, Young Fruit Color, Old or Cooked Fruit Color, Linger Color, Linger Position, Linger Separation, Fruit Tip Shape, Fruit Base Narrowing, Surface Texture Fruit Skin, Fruit Skin Hardness, Crimped Nature

Fruit, Fruit Wall Thickness, Husk Weight, Fruit Length and Width Ratio, Fruit Shape, Fruit Type, Wet Seed Weight, Dry Seed Weight, Slime Pulp Color, Seed Cotyledon Color, Seed Longitudinal Shape, Number of Seeds Per Fruit, Seed Length, Width Seed.

\section{Data analysis}

Data analysis uses descriptive methods that simplify and organize data to obtain an overall picture of the observed object. In addition to the use of descriptive analysis, kinship analysis was performed using cluster data analysis and the SPSS software version 22 was obtained from the SPSS software version 22 then the matrix value was formed by a dendogram or a tree diagram where there were clear levels (hierarchies) between objects, from the most similar to the same. least like. The similarity matrix calculation is done manually, for nominal qualitative data (not having a score) calculated using the following formula.

Quantitative data is converted to ordinary qualitative data using frequency distribution. The final result of the similarity matrix is the average of the similarity matrix for each character in one sample, from the similarity matrix made a dendogram using SPSS software (Statictical Product and Service Solutions) version 22.

\section{RESULTS}

\section{Morphological Characteristics of Cocoa}

The results of the exploration of the types of cacao in Kampung Makian Village and Papaloang Village found morphological diversity of cocoa plants ranging from habitus to cacao endosperm. Identification was carried out on the population of cocoa plants in the villages of Kampung Makian and Papaloang Village there were 37 plant accessions. Morphological characters were observed as much 43 characters, ranging from the shape of trees, branches, leaves, flowers and fruit of cocoa plants. Samples taken from the villages of Kampung Makian and Papaloang Village were taken based on plots on the community's cocoa plantations. There are five plots in each good, lush leaves, and good fruit. The shape of trees, 
branches, leaves, flowers, and fruit of cacao plants is an example of characterization of cacao plants and these characters are also characters that are influenced by environmental factors that cause diversity in cocoa plants.

Cacao must have growth
The diversity of morphological characters in each tree is different in line with the type of cocoa found. Morphological characters and types of cocoa found in the exploration of cocoa plants in the villages of Kampung Makian and Papaloang can be seen in the following Table 1:

Table 1. Morphological character 5 types of cacao plants found in the villages of Kampung Makian and Papaloang

\begin{tabular}{|c|l|l|l|l|l|l|}
\hline Code & $\begin{array}{c}\text { Morphological } \\
\text { Character }\end{array}$ & \multicolumn{1}{|c|}{ Forastero } & Angoleta & Cundeamor & Amelonado & Cabacillo \\
\hline A & Habitat Form & good & medium & very good & medium & ugly \\
\hline B & Jorket Formation & lots & lots & intermediate & intermediate & intermediate \\
\hline C & $\begin{array}{l}\text { Tinge of old leaf } \\
\text { color }\end{array}$ & mid & There is no & little & strong & mid \\
\hline D & Flower stalk color & reddish green & green & green & red & reddish \\
\hline E & Young fruit color & green & green & green & red & yellowish \\
\hline F & Ripe fruit color & yellow & $\begin{array}{l}\text { yellowish } \\
\text { green }\end{array}$ & orange & orange & reddish \\
\hline G & Linger position & $\begin{array}{l}\text { the same } \\
\text { distance }\end{array}$ & $\begin{array}{l}\text { in pairs } \\
\text { the same } \\
\text { distance }\end{array}$ & in pairs & $\begin{array}{l}\text { the same } \\
\text { distance }\end{array}$ \\
\hline H & Fruit tip shape & little & little & wide & wide & wide \\
\hline I & $\begin{array}{l}\text { Fruit skin surface } \\
\text { texture }\end{array}$ & there is no & mid & mid & little & there is no \\
\hline J & Fruit shape & little & mid & little & mid & there is no \\
\hline K & $\begin{array}{l}\text { Seed longitudinal } \\
\text { shape }\end{array}$ & Obevate & Eliptic & Obevate & Eliptic & Obevate \\
\hline L & Endosperm color & dark purple & Violet & dark purple & dark purple & dark purple \\
\hline
\end{tabular}
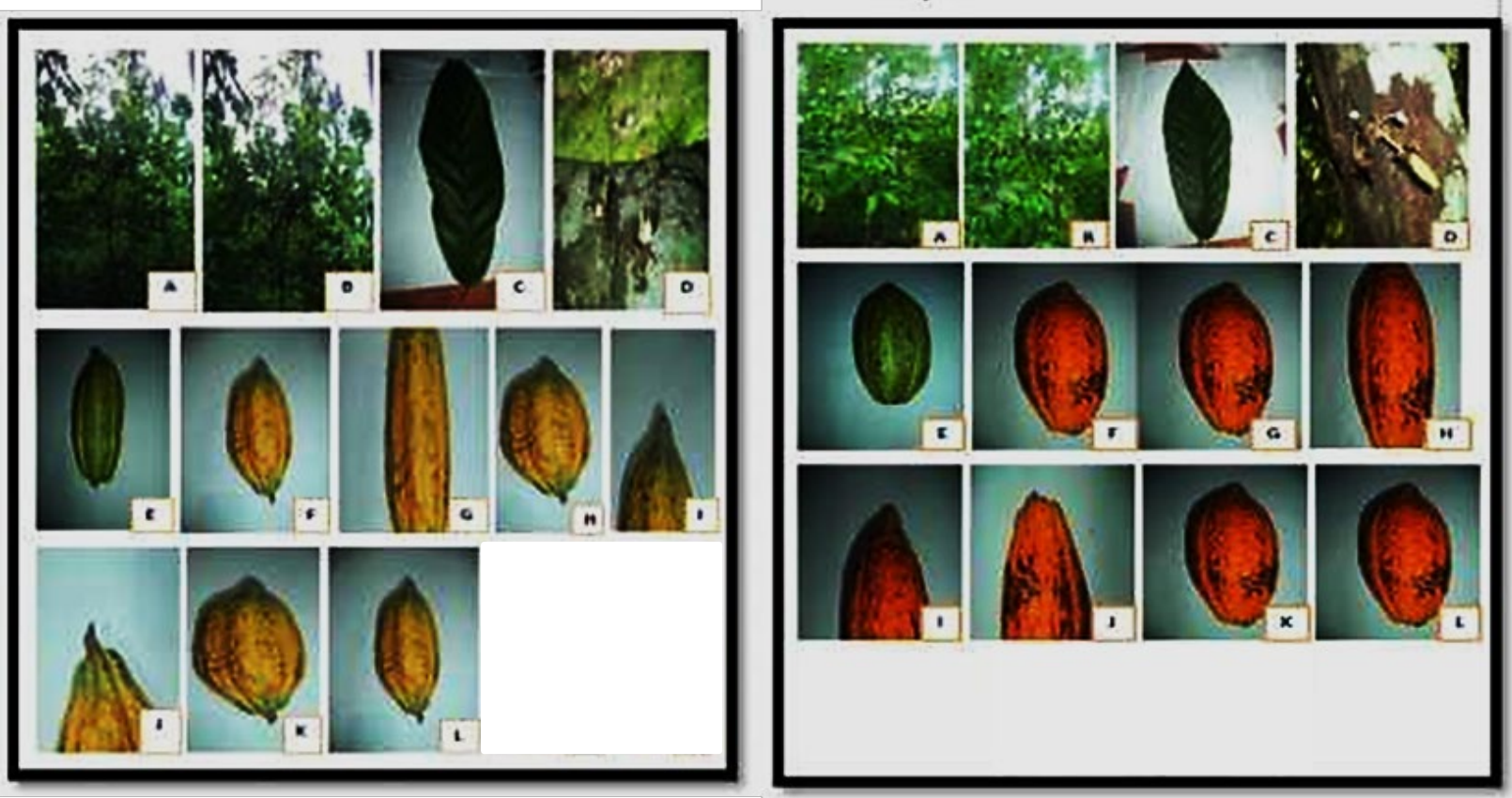

Figure 1. Character Morfology cacao plant variety Angolera : A) forms of habitus, B) jorket formation, C) tinge of old leaf color, D) flower stalk color, E) young fruit color, (F) ripe fruit color, G) linger position, H) fruit tip shape, I) fruit skin surface texture, J) fruit shape, K) seed longitudinal shape, and L) endosperm color. 
The Table 1, above shows 5 types of cacao plants found in the villages of Kampung Makian and Papaloang. Character forms of habitus, jorket formation, tinge of old leaf color, flower stalk color, young fruit color, ripe fruit color, linger position, linger separation, fruit tip shape, fruit base constriction, fruit skin surface texture, fruit shape, seed longitudinal shape, and endosperm color is a morphological marker of cocoa plants. Cundeamor type cocoa has the best form of habitus among others. In addition to the form of habitus, other characters also have different types of cocoa plants. For more details can be seen in the following Figure 1:

The results of the exploration of the diversity of cocoa morphology in villages in Kampung Makian and Desa Papaloang were found from as many as 43 morphological markers of cocoa plants, some of which contributed significantly to the diversity of cocoa plants, and some were not. Morphological markers that did not contribute significantly included habitus shape, plant height, canopy width, flower length. In addition to morphological characters, characters that contribute significantly to diversity. The results of descriptive analysis of 43 morphological characters of cocoa plants showed diverse diversity, namely: jorket formation, branch angle plagiotropes, dark leaf color tinge, young leaf color, leaf length, leaf width, leaf stalk, leaf stems, leaf tips, leaf edges, leaf edges, flower stalk color, flower length, edge of old fruit, young fruit color, old fruit color, color of the fruit ridge, ridge position, separation of the ridge, fruit tip shape, fruit base constriction, fruit skin hardness, fruit wrinkle properties, fruit wall thickness, weight fruit skin, ratio of length and width of fruit, ratio of length and width of fruit, type of fruit, wet seed weight, dry seed weight, mucus color, bjji cotyledon color, longitudinal shape of the seed, fruit appearance, and fruit width. Morphological character markers other than those mentioned are characters that do not contribute or significant influence on the diversity of cocoa morphology in Kampung Makian Village and Papaloang Village.

\section{DISCUSSION}

\section{Types of Cocoa on Bacan Island}

Based on the results of the identification of cacao plants in Kampung Makian Village and Papaloang Village, it was found 5 types of cacao according to their shape, namely: (1) Forastero cacao is raw cacao and bulk cacao which has strong tree growth and high productivity, produce fruit faster, relatively more susceptible to pests and diseases, the skin is rather rough but the surface is smooth, the fruit has a neck bottle or not, endosperm dark purple and flaky when wet, and the fruit skin is generally green with skin grooves deep fruit. (2) Angoleta cacao is a descendant of trinitario cocoa which is the result of a cross from criollo and forastero. Shaped more like a criollo, the skin is very rough, without bottle neck, large fruit size, round seeds, furrows in light purple endosperm color and has superior quality. (3) Cundeamor cacao is the same as angoleta, cundeamor is a result of crossing from criollo and forastero which is a regeneration of trinitario origin. Fruit shape such as angoleta, with rough skin, clearly visible bottle neck shape, flat seeds, with sweet taste, deep grooves and dark purple endosperm color. The resulting quality is superior. (4) Amelonado Cocoa The shape of an egg with a smooth skin texture, some have a bottle neck and some are not, flat seeds with a rather sweet taste, clear grooves with purple endosperm. The resulting quality is even superior. (5) Calbacillo Cocoa Fruit is short and round, fruit skin is very slippery, does not have a flat neck bottle with a bitter taste, a very shallow groove, endosperm color is purple, and the resulting quality is low.

\section{Morphological Characteristics of Cocoa on Bacan Island}

Genetic material for assembling materials superior cocoa cultivation is obtained by introduction, exploration, and selection. The development of cocoa plants in Bacan uses materials from seeds imported from Jember and Sulawesi, namely the clones DR1, DR2, ICCRI 04, Sulawesi 1, and Sulawesi 2. Morphological characterization results of 5 types of cocoa plants based on analysis of variations using anova analysis showed there is diversity between the two villages. Characters that show diversity are the formation of jorket, angle of plagiotropic branch, tinge of old leaf color, young leaf color, leaf length, leaf width, leaf shape, leaf edge, leaf tip, leaf stalk, long flower stalk, fruit size based on length, the color of young fruit, the color of old or ripe fruit, the color of the fruit ridge, the position of the fruit ridge, the separation of the fruit ridge, the shape of the fruit tip, narrowing of the base of the fruit, the hardness of the fruit skin, the fruit's wrinkling properties, fruit wall thickness, husk weight, ratio of fruit length and width , type of fruit, weight of wet seeds, beraj seeds dry, pulp color, fruit length, and fruit width. While that does not show diversity is the form of habitus, plant height, the length of the flower stalk, the surface texture of the fruit skin, and the width of the canopy length.

According to Rachmadi (2000), in a biological system the diversity of the appearance of plants in a population can be caused by the genetic diversity of the population compilers, the diversity of the environment, and the diversity of genotype $\mathrm{x}$ genetic factor interactions, then that diversity can be passed on to the next generation. In plants propagated by seed, gene segregation occurs from generation to generation. In self-pollinating plants which will continuously result in increased homozygosity which will cause increased genetic variability.

Specific cocoa in the Bacan area is carried out through exploration of resistant genotypes in the previous area then brought to Bacan as an endemic area of attack. In this case the cocoa plantations which are mostly derived from hybrid seeds in Jember and Sulawesi are used as a source of genetic material to obtain pest and disease resistant 
genotypes through exploration activities. Hybrid planting material is the result of crossing between clonal elders that has the power characteristic yield, yield quality, and pest or disease resistance so that hybrid plantations consist of genotypes of recombination between these superior traits, but over time the superior planting material of cocoa in Bacan has not been renewed again resulting in large production failures which led to complaints the farmers.

\section{Kinship of Cocoa Plants}

The 10 clove plots related to Bacan Island each have similarities between one tree and another. The first cluster shows the closest kinship, the second cluster shows the closest, while the third cluster shows the kinship that is not too close. But in essence the two Klalster have a real kinship relationship. The results of the analysis showed that a very close relationship was related to trees 5 and 6 which were both in plot 2 . Whereas the farthest were the trees 18 in plot 5. But there is also a close kinship but different plots, for example trees 1 and 12 are different from plots, tree 1 in plot 1 while tree 12 in plot 4 . The same cluster is formed with almost the same genotype. This shows that the genotypes were formed from the same population,

so that the kinship is closer. The closer the kinship is, the stronger the genetic similarity of genotypes in the group, so that if the crossing is done between individuals in the same group (with a close kinship level) it means that the individuals genetically have a close kinship relationship (Erlina, 2011).

\section{CONCLUSION}

Based on the research results obtained, the conclusions can be made as follows:

1. Found 5 types of cocoa plants in the village of Kampung Makian and Papaloang Village on Bacan Island. The types of cacao plants found were Forastero, Angoleta, Cundeamor, Amelonado, and Cabacillo.

2. There is a kinship relationship between each sample. Trees 5 and 6 have a very close kinship, while tree 28 has a very distant kinship.

3. As the best recommendation for superior cocoa planting material, it is found in Papaloang Village plot 3 trees 2 .

\section{REFERENCES}

[1] Abdullah, M.A.N., R.R. Noor dan H. Martojo, D.D. Solihin dan E. Handiwirawan. 2007. Keragaman fenotipik sapi Aceh di Nanggroe Aceh Darussalam. J. Indon. Trop. Anim. Agric. 32 (1): 11-12.

[2] Agung Wahyu Susilo, 2007. Akselerasi Program Pemuliaan Tanaman Kakao (Theobroma Cacao L.) Melalui Pemanfaatan
Penanda Molekuler Dalam Proses Seleksi.

[3] Bappenas 2003. Strategi dan Rencana Aksi

KeanekaragamanHayatiIndonesia 2003-2020

[Dokumen Nasional ].

[4] Badan Perencanaan Pembangunan Nasional. JakartaBalai Penelitian Industri dan Penyegar, 2017.Analisis Keragaman Genetik 28 Nomor Koleksi Kakao (Thobroma Cacao L.) Berdasarkan Marka SSR.

[5] Cahyaditha., A. Ayu 2011. Biologi Tanaman Kakao. Universitas of Sumatera Cahyono, B.2010.Sukses Bertanam Kakao. Pustaka Min, Jakarta.

[6] Dahlan, M. M. (2011). Komposisi Jenis Tumbuhan Bawah Pada Tegakan Sengon (Paraserianthes falcataria L. Nelsen). Bandung, Indonesia: Intitut Pertanian Bogor.

[7] Dahlan, F. 2014. Peningkatan Daya Saing Ekspor Produk Olahan Kakao Indonesia di Pasar Internasional, Jurnal Administrasi Bisnis.

[8] Direktorat Jenderal Perkebunan, 2017.Penyebaran Komoditi Kakao dan Luas Daerah Produksi Perkebunan Rakyat.

[9] Erlina, 2011. Kekerabatan Morfologi Tanaman Kakao (Theobroma Cacao L.)

[10] Griffin, Sedgley. 1989. Physiology of Woody Plants.

[11] Harsono, T. 2011. Taksonomi Tumbuhan Tingkat Tinggi. FMIPA Unimed, Medan.

[12] Kementrian Pertanian Direktorat Jenderal Perkebunan, 2010. Panduan Teknis Budidaya Tanaman Kakao (Theobroma Cacao L.)

[13] Kuswartini, S., Rubiyo, Setiawan, A., Purwantara, A., dan Sudarsono, 2010, Analisis Online Jurna Of Natural Science, Vol .3(3): 239 - 246 December 2014

[14] Nazir, Mohammad, Ph.d.2003. Pengembangan Dinamika Kelompok Tani

[15] Nchrawy., A. Adyaksa 2013. Kajian Kehilangan Hasil Kakao (Theobroma cacao. L) Akobat Penyakit Busuk Buah Kakao di Kecamatan Bacan Kbupaten Halmahera Selatan.

[16] Pusat Penelitian dan Pengembangn Perkebunan 2010. Panduan Lengkap Budiday Kakao. Penerbit Agromedia Pustaka, Jakarta.

[17] Pusat penelitian dan Perkembangan Perkebunan, 2010

[18] Sada, J.T dan Tanjung, R.H.R. (2010).Keragaman Tumbuhan Obat Tradisional di Kampung Nansfori Distrik Supiori Utara. 